\title{
Plant Extract Approaches to the Management of Guava Fruit Fly Bactrocera correcta (Bezzi)
}

\author{
Neerja Agrawal*, Shyam Kumar Verma and Ram Kewal \\ Department of Entomology, Chandra Shekhar Azad University of Agriculture and \\ Technology, Kanpur-208002 India \\ *Corresponding author
}

\section{A B S T R A C T}

\begin{tabular}{|c|}
\hline Keywords \\
\hline $\begin{array}{l}\text { Guava fruit, } \\
\text { Bactrocera } \\
\text { correcta, Maggots, } \\
\text { Neem, Pupal } \\
\text { treatment }\end{array}$ \\
\hline Article Info \\
\hline $\begin{array}{l}\text { Accepted: } \\
17 \text { April } 2019 \\
\text { Available Online: } \\
10 \text { May } 2019\end{array}$ \\
\hline
\end{tabular}

\section{Introduction}

Guava (Psidium guava L.); a very productive, highly profitable fruit having wide adaptability with higher return per unit area and rich source of vitamin C (Ascorbic acid), is one of the most important fruit crops in India. Fruit flies (Diptera: tephritidae) are most economically important fruit pests
Guava is an important fruit of India, rich in minerals and vitamin C. Fruit flies are one of the most noxious pest of guava which can cause tremendous loss to farmers due to its infestation. Since it is a well established fact that pesticides cause health hazards and damage the environment, experiments were laid out during the year 2011-12 and 2012-13 for evaluating bio-efficacy of indigenous plant extracts on guava fruit fly Bactrocera correcta (Bezzi) on its emergence and longevity by pupal treatment; as reproductive inhibitor by fruit treatment and effect on maggots of guava fruit fly by sandwich method under the laboratory conditions at departmental of Entomology. The present investigations deal with 10 indigenous plants such as Azadirachta indica, Parthenium histophorum, Norium oleander, Annona squamosa, Cantharanthus roseus, Lantana camera, Pongamia pinnata, Ocimum sanctum, Dhatura stramonium and Apocynum cannabium used as methanol extract as possible management tools to manage population of guava fruit fly $B$. correcta. As indicated in various experiments; Neem Azadirachta indica possesses strong insecticidal and sterilent activity at higher concentration of 8 per cent followed Lantana camera, Pongamia pinnata, Ocimum sanctum and Dhatura stramonium. The effect of plant extracts as inhibitor of reproductive potential displayed a gradual decrease in fecundity with the increase of concentration. In this trial Neem treatment affected fecundity more than longevity, therefore, use of Azadirachtin based compound in insecticidal baits appeared possible especially when mixed with attractant substances. 
2005).The adult lays eggs in the fruit causing blemishes and discoloration and the larvae bore inside the fruit making it unfit for consumption. The guava fruit fly, Bactrocera correcta (Bezzi) (Diptera: Tephritidae) is one of the most destructive pests in the genus Bactrocera (Wang, 1996). The fly was first recorded in 1916 at Bihar, India (Bezzi, 1916) and is now distributed throughout most countries of south East Asia, including Pakistan, India, Nepal, Burma, Thailand, Sri Lanka, Vietnam and China (Wang, 1996; Drew and Raghu, 2002). B. correcta is listed as a quarantine pest by most countries worldwide (White and Elson-Harris, 1992).

Plant protection products (more commonly known as pesticides) are widely used in agriculture to increase the yield, improve the quality, and extend the storage life of food crops (Fernandez-Alba and Garc 2008). The use of chemical pesticides in fruit is still necessary to guarantee the worldwide food supply. However, the presence of residues in treated fruit with possible health risk to consumers is a global concern. Therefore, in the present research paper, an effort has been made to find out the bio-efficacy of indigenous plant extracts as eco-friendly and easily available botanical pesticides, against guava fruit fly $B$. correcta.

\section{Materials and Methods}

\section{Cage experiments}

\section{Plant material}

To study various plant extracts on fruit fly Bactrocera correcta on guava fruit, 10 plants of indigenous origin were selected to test the emergence, longevity, ovipositor and mortality of maggots in the laboratory of Department of Entomology at Chandra Shekhar Azad University of Agriculture and Technology, Kanpur, Uttar Pradesh, India.

\section{Insect material}

\section{Maintenance of culture}

For maintenance of fresh culture, infested fruits of guava were collected from guava orchard at farmer's field. The collected fruits were kept in rearing cage $30 \times 30 \times 30 \mathrm{~cm}$ in departmental laboratory containing sterilized sand at the bottom of cage $(10 \mathrm{~cm}$.) for pupation. After the emergence of adults, males and females were transferred in cage for copulation and allowed egg laying on fresh fruit of guava. Protenex was provided to these adults for food. The eggs were laid by females in small cluster just under the skin of fruit with its ovipositor. These fruits were collected and transferred to another cage for hatching of the eggs. $10 \mathrm{~cm}$ sterilized sand was put at the bottom of the cage and water was sprinkled at regular intervals. After a few days the larvae inside the fruit pupated in sand. The temperature was maintained at $25 \pm 3^{\circ} \mathrm{C}$ and $\mathrm{RH}-75 \%$.

\section{Preparation of plant extract}

Preparation of methanolic plant extract was done according to Kulkarni and Joshi (1997). The leaves of indigenous plants such as $A$. indica, $P$. histophorom, $N$. oleander, $A$. squamosa, $C$. roseus, L. camera, $P$. pinnata, $O$. sanctum, $D$. stramonium and $A$. cannabium were collected, shade dried and powdered. Extracts were prepared using $100 \mathrm{ml}$ of methanol added in beaker containing $20 \mathrm{gm}$ of grinded powder of each plant. After about 24 hours, this mixture was passed through a coarse filter paper. The desired quantity of methanol was then added in to filtered plant material in order to make the volume of 100 $\mathrm{ml}$. thus 20 per cent (w/v) stock solution of each plant extract was prepared. This stock solution was further diluted in distilled water for experimental uses. 
For preparation of different concentrations of plant extracts following formula was applied:-

Amount of formulation $=\frac{\text { Concentration required }(\%) X \text { Quantity required }}{\text { Concentration of technical material }}$

\section{Pupal dipping}

15 Healthy pupae were collected from fresh culture of fruit fly colony and dipped in 2, 5, and 8 per cent plant extract for 5 minutes. These were transferred to jars (1.5lit capacity) containing sterilized sand for emergence in three replications. The data was recorded at 8 , 10 and 12 days for adult emergence and longevity. Uniform cultural practices were applied to all the treatments. Ripe fruits were kept for fresh infestation.

\section{Egg laying inhibitor}

Whole fruits were treated with plant extract by selecting guava fruit of equal size and spraying with 2, 5 and 8 percent plant extracts in three replications. These were kept in jars of 1.5 lit capacities with $5 \mathrm{~cm}$ sterilized sand at bottom. Four pairs of guava fruit fly were released in each jar for egg laying in treated fruit. Old fruit was replaced with fresh treated fruit after every $4^{\text {th }}$ day. The fruit was examined for fresh eggs laid by examining the hatched larvae after 4, 6 and 8 days.

\section{Effect on maggots}

The experiment was conducted in laboratory with 11 treatments including control with three replications. Three consecutive instars $\left(\mathrm{I}^{\mathrm{st}}, \mathrm{II}^{\mathrm{nd}}\right.$ and $\mathrm{III}^{\mathrm{rd}}$ ) were tested by sandwich method. The fruit was cut into two halves and $1 \mathrm{ml}$ solution of different plant extracts was sprayed on it. 15 maggots of three consecutive instars were released on the cut fruit and covered with the second halves. The data were recorded after 6,8 and 10 days for their mortality.

\section{Laboratory hygiene}

High hygienic standards were maintained in the laboratory at all production stages. Whole fruit, fruit domes, and important rearing materials such as rearing cages, trays, sponges, racks etc. were frequently rinsed with $0.025 \% \mathrm{NaCl}$ followed by several rinses in sterile distilled water to eliminate bacterial and fungal infection. The benches were disinfected by wiping with $70 \%$ ethanol every morning to prevent infestations by mite which are common causes for drastic reduction in adult emergence.

\section{Statistical design}

All experiments testing indigenous plant extracts on guava fruit fly were analyzed by following Completely Randomized Design with 11 treatments and 3 replications.

\section{Results and Discussion}

\section{Emergence of adults from treated pupae}

Various indigenous plant extracts were tested at 2, 5 and 8 per cent and it was observed that after 6,8 and 10 days interval, minimum mean emergence of adults recorded was 13.33, 8.89 and 5.93 with 2, 5 and 8 per cent Neem leaf extract, respectively, which was statistically significantly superior among all treatments. This was followed by $P$. histophorom, D. stramonium, P. pinnata and O. Sanctum (Table 1).

Oak (Apocynum cannabium) extract was found least effective in mean emergence of adult fruit flies with maximum 43.70, 40.00 and 36.30 per cent adults emerged at 2, 5 and 8 per cent plant extract, respectively, after 10 days of treatment. Longevity of adults was also maximum recording $61.48,48.89$ and 44.44 per cent mean survival at 2, 5 and 8 per cent concentration, respectively. It was 
observed that 8 per cent plant extracts were found most effective. Neem leaf extract was found highly significant in reducing adult emergence (Table 2).

\section{Longevity of adults}

The longevity of guava fruit fly adult after emergence from treated pupae was assessed after 10, 15 and 20 days of emergence. The indigenous plant extracts at 2, 5 and 8 per cent were tested in the laboratory. Neem leaf extract at 8 per cent was found most effective with minimum 7.41 per cent survival of adults. Parthenium, Dhatura and Karanj were also significantly superior over rest of the treatments at 8 percent, with mean survival of $11.11,13.33$ and 16.30 per cent, respectively. As regards the overall impact of botanicals, 8 percent extract was most effective in minimising the longevity. Neem leaf extract was found highly significant in reducing adult emergence and longevity of adults of Bactrocera correcta (Bezzi) in guava fruits. Oak, lantana and custard apple were least effective as higher survival percentage was recorded (ranging 34.82-44.44 per cent survival) with them.

\section{Reproductive inhibitor}

Different plant extracts at 2, 5 and 8 per cent were tested as egg laying inhibiter by fruit treatment based on number of eggs hatched. 4 pairs of $B$. correcta adults were released in each jar for egg laying. Data were recorded after 4,6 and 8 days of release of adults. Among all the concentrations tested, $8 \%$ per cent extracts were proved most promising in inhibiting reproductive capacity of adults as shown in Table 3. The egg fertility was lower in Neem leaf extracts where minimum egg fertility of $8.89,6.67$ and 4.44 per cent was recorded after 4, 6 and 8 days of release, respectively. In order of efficacy, Parthenium followed by Dhatura registered a mean of
8.89 and 11.11 per cent egg fertility after the total observation period. Oak (A. Cannabium) was proved least effective followed by Lantana (L. camera), registering 26.67 per cent and 24.4 mean egg fertility.

It is worth mentioning here that Neem and Parthenium extracts were statistically at par while Dhatura and Karanj did not show significance among themselves. Alcohol applied as standard showed highly deterrent effect on reproductive capacity of female as it was significantly superior in all other treatments. All the treatments were found significantly superior from control.

\section{Effect on maggots}

Different instars of larvae of $B$. correcta were fed on treated slice of guava by sandwich method. The concentrations used were 2,5 and 8 per cent. Mortality of maggots was recorded at 6,8 and 10 day intervals (Table 4) (Fig. 1, 2 and 3).

Among all the treatments, Neem leaf extract at 8 per cent imparted maximum mortality of I, II and III instar larvae, at 6, 8 and 10 days after treatment. The mean mortality was $47.41,45.19$ and 37.78 per cent for I, II and III instar larvae in Neem leaf extract at 8 per cent. Oak with minimum mortality per cent followed by Lantana and custard apple showed that their extracts were poor in causing high mortality in maggots. Among all plant extracts Neem formulation was found most effective and I instar larvae were more susceptible in comparison to II and III instar. This means that early, stage of maggot can be managed by indigenous plant extracts. However, alcohol as standard solvent caused maximum mortality, the sequence of intensity of different plant extracts was recorded as follows: Neem $>$ Parthenium $>$ Dhatura $>$ Karanj $>$ Tulsi >Kaner $>$ Vinca rosea $>$ Custard apple $>$ Lantana and Oak. 
The present investigation deals with the first attempt with indigenous plant extracts as possible management tools to manage population of guava fruit fly Bactrcera correcta aiming to reduce pesticide application. A viable crude plant extracts needs to be finely tested to be successful with the guava growers.

In controlled conditions, among ten plant extracts tested, Neem leaf extract was found most effective after 6,8 and 10 days, followed by Parthenium and Dhatura with excellent results. Tulsi and Karanj also showed significant results. Oak was least effective with maximum mean emergence of adults which was closely followed by lantana at all concentrations. It is in line with the previous work by Stark et al., (1990) who reported effect of Azadirachtin on metamorphosis, longevity and reproduction of three tephritid fruit fly species. The adult emergence was inhibited by $1440 \mathrm{ppm}$ for $D$. dorsalis and $1010 \mathrm{ppm}$ for B. cucurbitae. Karnataka et al., (2007) determined effect of Tulsi (O. sanctum) leaf extract on the growth and development of Spilarctia obliqua and found lowest adult emergence with $10 \%$ leaf extracts. Agrawal and Saroj (2003) found that fresh Neem oil at 2 per cent showed pupal inhibition and inhibitory effect on adult emergence in the mustered sawfly Athalia proxima (Clug.). Shivayya and Kumar (2008) managed melon fruit fly $B$. cucurbitae (Coquillett) by using plant products and found that adult emergence was lowest in Neem oil treatment whereas highest per cent infestation was in custard apple seed extracts. Pupal dipping method of B. Cucurbitae was studied by Agrawal and Dev (2013a and 2015) who reported Neem and Parthenium extracts as most promising. These results are in conformity to the present investigation where Neem leaf extract performed best with minimum emergence while Oak $A$. cannabium resulted in higher emergence of fly from treated pupae.
In the present study longevity of guava fruit fly was minimum with 7.41 per cent survival. Parthenium, Dhatura and Karanj with survival of $11.11,13.33$ and 16.30 per cent were also significantly superior over rest of the treatments at 8 per cent concentration.

As regards reproductive inhibition by these plants, egg fertility was at par in NLE and Parthenium while Dhatura and Karanj did not show significance among themselves. Neem seed kernel extract had a deterrent effect on oviposition of the Bactrocera dorsalis (Hendal) as evaluated by Chien et al., (1996) in laboratory on guava fruit fly. They found that concentration ranging 0.2 to 0.4 per cent reduced the number of eggs laid in treated guava. Hasan (1998) reported the repellency effect of NSKE at active ingredient $7 \%$ Azadirachtin by fruit dipping method and subsequently exposed to cage of adult fly, Bactrocera tryoni (Frogg). Khan et al., (2007) confirmed that Neem can be effectively used as fecundity deterrent for the control of Bactrocera spp. These results indicate that plants may possess strong sterilant activity and are in conformity to the present findings. However, literature seems silent on other plant extracts used such as Parthenium, Dhatura and Karanj which cannot be overlooked as reproductive inhibitor.

Experiments conducted on larval mortality by sandwich method revealed that, again Neem leaf extract at 8 per cent was most suitable for mortality of I, II and III instar maggots (pooled 43.46\%). Pooled data (Fig. 1, 2 and 3) revealed that Oak with minimum mortality of 16.05 percent, Lantana (19.01 per cent) and custard apple (21.73 per cent) showed that their extracts were poor in causing high mortality in maggots. Kulkarni et al., (1997) reported antifeeding property of Lantana camara against teak skeletonizer Eutectona machaeraelis Walks. Fakhari and Murad (2004) reported efficacy of Neem product on forth instar nymph of red cotton bug, while 
Ramesh et al., (2006) reported larvicidal and repellent activity of $A$. Indica on culex qeuquefaseilatus. All these results are very much similar to the present investigation where Neem leaf extracts (NLE) was found to be most effective. Ocimum leaf extract (Tulsi) was exploited by Karnatka et al., (2007) against $S$. obliqua where highest larval mortality and lowest pupal weight and adult emergence with $10 \%$ O. sactum leaf extract were noticed. Sharma and Rathore (2006) reported the efficacy of NSK, Vinca rosea, Annona and Dhatura leaf powder on development of Challosobruchus chinensis in pigeon pea and found that NSK and Annona seed powder gave complete protection against the pest. In the present investigations Tulsi, $O$. sactum showed higher bio-efficacy against different instars of guava fruit fly but Annona was comparatively inferior.

Effect of plant extracts on different fruit flies infesting fruits and vegetables were explored by many workers such as Tiwari (2001) who reported that $P$. pinnata and $A$. indica significantly reduced the population of $B$. cucurbitae (Coquillett) and reduced transmission of cucumber mosaic virus by $B$. cucurbitae (Coquillett) in Cucumis melo cultivar. Siskos et al., (2007) worked on insecticidal activity of plant extracts of Citrus aurantium against olive fruit fly Bactrocera olae (Gmll) and found that petroleum ether extract from seed showed insecticidal properties. According to Khan et al., (2007) Neem leaf dust and commercial formulation compound affected the longevity of $B$. cucurbitae and $B$. dorsalis and confirmed that Neem can be effectively used as safe insecticide for control of Bactrocera spp. Mondal and Ghatak (2009) tested some indigenous plant product against $B$. cucurbitae and reported that NSKE and methanol extracts of Annona squamosa caused significant reduction in fruit damage. Kaur et al., (2010) studied inhibitory effect of Acacia auriculiformis on B. cucurbitae (Coquillett) and reported that acetone extract was more toxic than water extract in controlling melon fruit fly.

Utilization of natural products derived from indigenous plants to control insect pest have been reported by different workers but a thorough scan of literature revealed that bioefficacy of indigenous plant extracts against guava fruit fly. B. correcta (Bezzi) has not yet been explored.

Table.1 Different indigenous plants used for making extracts

\begin{tabular}{|l|l|l|}
\hline Sl. No. & Common Name & Scientific Name \\
\hline $\mathbf{1}$ & Neem & Azadirachta indica \\
\hline $\mathbf{2}$ & Parthenium & Parthenium histophorom \\
\hline $\mathbf{3}$ & Kaner & Norium oleander \\
\hline $\mathbf{4}$ & Custard apple & Annona squamosa \\
\hline $\mathbf{5}$ & Vinca rosea & Cantharanthus roseus \\
\hline $\mathbf{6}$ & Lantana & Lantana camera \\
\hline $\mathbf{7}$ & Karanj & Pongamia pinnata \\
\hline $\mathbf{8}$ & Tulsi & Ocimum sanctum \\
\hline $\mathbf{9}$ & Dhatura & Dhatura stramonium \\
\hline $\mathbf{1 0}$ & Oak & Apocynum cannabium \\
\hline
\end{tabular}


Table. 2 Bio-efficacy of indigenous plant extracts on treated pupae of guava fruit fly Bactrocera correcta based on emergence and longevity of adults

\begin{tabular}{|l|l|l|l|l|l|l|l|}
\hline \multirow{2}{*}{$\begin{array}{l}\text { SI } \\
\text { No. }\end{array}$} & Treatments & \multicolumn{3}{|l|}{ Percent mean emergence of adults } & \multicolumn{3}{l|}{$\begin{array}{l}\text { Percent mean longevity of adults emerged } \\
\text { from treated pupae }\end{array}$} \\
\cline { 5 - 8 } & 2 percent & 5 percent & 8 percent & 2 percent & 5 percent & 8 percent \\
\hline $\mathbf{1}$ & $\begin{array}{l}\text { Azadirachta } \\
\text { indica }\end{array}$ & $13.33(21.41)$ & $8.89(17.34)$ & $5.93(14.09)$ & $14.07(22.03)$ & $11.85(20.13)$ & $7.41(15.79)$ \\
\hline $\mathbf{2}$ & $\begin{array}{l}\text { Parthenium } \\
\text { histophorom }\end{array}$ & $15.56(23.23)$ & $11.85(20.13)$ & $9.63(18.07)$ & $17.78(24.93)$ & $15.56(23.23)$ & $11.11(19.47)$ \\
\hline $\mathbf{3}$ & $\begin{array}{l}\text { Norium } \\
\text { oleander }\end{array}$ & $29.63(32.97)$ & $26.67(31.09)$ & $22.96(28.63)$ & $39.26(38.79)$ & $29.63(32.97)$ & $25.19(30.12)$ \\
\hline $\mathbf{4}$ & $\begin{array}{l}\text { Annona } \\
\text { squamosa }\end{array}$ & $37.04(37.48)$ & $33.33(35.26)$ & $30.37(33.44)$ & $49.63(44.78)$ & $39.26(38.79)$ & $34.82(36.16)$ \\
\hline $\mathbf{5}$ & $\begin{array}{l}\text { Cantharanths } \\
\text { roseus }\end{array}$ & $32.59(34.81)$ & $29.63(32.97)$ & $25.92(30.60)$ & $45.18(42.23)$ & $35.56(36.60)$ & $29.63(32.97)$ \\
\hline $\mathbf{6}$ & $\begin{array}{l}\text { Lantana } \\
\text { camera }\end{array}$ & $40.74(39.66)$ & $35.56(36.60)$ & $32.59(34.81)$ & $57.04(49.04)$ & $44.44(41.80$ & $40.74(39.66)$ \\
\hline $\mathbf{7}$ & $\begin{array}{l}\text { Pongamia } \\
\text { pinnata }\end{array}$ & $22.96(28.63)$ & $19.26(26.03)$ & $16.30(23.81)$ & $30.37(33.44)$ & $20.74(27.09)$ & $16.30(23.81)$ \\
\hline $\mathbf{8}$ & $\begin{array}{l}\text { Ocimum } \\
\text { sanctum }\end{array}$ & $25.92(30.60)$ & $22.96(28.63)$ & $19.26(26.03)$ & $31.11(33.90)$ & $24.44(29.62)$ & $20.00(26.39)$ \\
\hline $\mathbf{9}$ & $\begin{array}{l}\text { Dhatura } \\
\text { stramonium }\end{array}$ & $18.52(25.48)$ & $15.56(23.23)$ & $20.74(27.09)$ & $22.22(28.12)$ & $17.78(24.93)$ & $13.33(21.41)$ \\
\hline $\mathbf{1 0}$ & $\begin{array}{l}\text { Apocynum } \\
\text { cannabium }\end{array}$ & $43.70(41.38)$ & $40.00(39.14)$ & $36.30(36.97)$ & $61.48(51.63)$ & $48.89(44.35)$ & $44.44(41.80)$ \\
\hline $\mathbf{1 1}$ & Alcohol & $8.89(17.34)$ & $6.67(14.96)$ & $3.70(11.09)$ & $10.37(18.78)$ & $7.41(15.79)$ & $4.44(12.16)$ \\
\hline $\mathbf{1 2}$ & \begin{tabular}{l} 
Control \\
\hline
\end{tabular} & $88.15(70.70)$ & $88.89(70.52)$ & $85.93(67.96)$ & $69.63(56.72)$ & $65.19(53.84)$ & $63.70(52.95)$ \\
\hline SE & $(1.79)$ & $(1.39)$ & $(1.13)$ & $(1.33)$ & $(1.09)$ & $(1.20)$ \\
\hline CD & $(3.70)$ & $(2.87)$ & $(2.33)$ & $(2.75)$ & $(2.04)$ & $(2.12)$ \\
\hline
\end{tabular}

Figures in parentheses are angular transformed values

Table.3 Mean per cent of hatched larvae after 8 days of fruit treatment.

\begin{tabular}{|l|l|c|c|c|}
\hline \multirow{2}{*}{$\begin{array}{l}\text { No. } \\
\text { No }\end{array}$} & \multicolumn{1}{|c|}{ Treatments } & \multicolumn{3}{|c|}{ Mean percent of eggs hatched on treated fruit } \\
\cline { 3 - 5 } & & 2 percent & 5 percent & 8 percent \\
\hline $\mathbf{1 .}$ & Azadirachta indica & $14.07(22.03)$ & $11.11(19.47)$ & $6.67(14.960)$ \\
\hline $\mathbf{2 .}$ & Parthenium histophorom & $18.52(25.48)$ & $13.33(21.41)$ & $8.89(17.341)$ \\
\hline $\mathbf{3 .}$ & Norium oleander & $32.59(34.81)$ & $22.96(28.63)$ & $17.78(24.936)$ \\
\hline $\mathbf{4 .}$ & Annona squamosa & $37.04(37.41)$ & $27.41(31.57)$ & $22.22(28.129)$ \\
\hline $\mathbf{5 .}$ & Cantharanthus roseus & $34.81(36.15)$ & $26.66(31.08)$ & $20.00(26.263)$ \\
\hline $\mathbf{6 .}$ & Lantana camera & $40.74(39.66)$ & $25.93(30.61)$ & $24.44(29.621)$ \\
\hline $\mathbf{7 .}$ & Pongamia pinnata & $25.18(30.11)$ & $18.52(25.48)$ & $13.33(21.419)$ \\
\hline $\mathbf{8 .}$ & Ocimum sanctum & $28.15(32.04)$ & $18.52(25.48)$ & $15.56(23.234)$ \\
\hline $\mathbf{9 .}$ & Dhatura stramonium & $22.22(28.12)$ & $15.18(27.09)$ & $11.11(19.472)$ \\
\hline $\mathbf{1 0}$. & Apocynum cannabium & $44.44(41.80)$ & $33.33(30.11)$ & $26.67(31.090)$ \\
\hline $\mathbf{1 1 .}$ & Alcohol & $11.11(19.47)$ & $7.40(23.81)$ & $4.44(12.161)$ \\
\hline $\mathbf{1 2 .}$ & Control & $65.93(54.32)$ & $73.71(49.07)$ & $63.70(52.952)$ \\
\hline & SE & $(1.33)$ & $(0.96)$ & $(1.38)$ \\
\hline & CD & $(2.75)$ & $(1.99)$ & $(2.84)$ \\
\hline
\end{tabular}

Figures in Parentheses are angular Transformed values. 
Table.4 Bio-efficacy of plant extracts on different instars against guava fruit fly Bactrocera correcta by sandwich method based on mortality

\begin{tabular}{|c|c|c|c|c|c|c|c|c|c|c|}
\hline \multirow{4}{*}{$\begin{array}{l}\text { SI } \\
\text { No. }\end{array}$} & \multirow[t]{4}{*}{ Treatments } & \multicolumn{9}{|c|}{ Mean mortality (\%) of maggots of guava fruit fly Batrocera dorsalis at different stages } \\
\hline & & \multicolumn{3}{|c|}{$\mathrm{I}^{\mathrm{st}}$ Instar } & \multicolumn{3}{|c|}{$2^{\text {nd }}$ Instar } & \multicolumn{3}{|c|}{$3^{\text {rd }}$ Instar } \\
\hline & & \multicolumn{3}{|c|}{ Concentration of extract } & \multicolumn{3}{|c|}{ Concentration of extract } & \multicolumn{3}{|c|}{ Concentration of extract } \\
\hline & & $2 \%$ & $5 \%$ & $8 \%$ & $2 \%$ & $5 \%$ & $8 \%$ & $2 \%$ & $5 \%$ & $8 \%$ \\
\hline 1. & $\begin{array}{l}\text { Azadirachta } \\
\text { indica }\end{array}$ & $\begin{array}{c}37.04 \\
(37.49)\end{array}$ & $\begin{array}{c}44.45 \\
(41.81)\end{array}$ & $\begin{array}{c}47.41 \\
(43.51)\end{array}$ & $\begin{array}{c}31.85 \\
(34.35)\end{array}$ & $\begin{array}{c}41.48 \\
(40.09)\end{array}$ & $\begin{array}{c}45.19 \\
(42.23)\end{array}$ & $\begin{array}{c}26.67 \\
(31.09)\end{array}$ & $\begin{array}{c}33.33 \\
(35.26)\end{array}$ & $\begin{array}{c}37.78 \\
(73.92)\end{array}$ \\
\hline 2. & $\begin{array}{l}\text { Parthenium } \\
\text { histophorom }\end{array}$ & $\begin{array}{c}34.08 \\
(35.71)\end{array}$ & $\begin{array}{c}41.48 \\
(40.09)\end{array}$ & $\begin{array}{c}43.71 \\
(41.38)\end{array}$ & $\begin{array}{c}28.89 \\
(32.51)\end{array}$ & $\begin{array}{c}38.52 \\
(38.36)\end{array}$ & $\begin{array}{c}41.48 \\
(40.09)\end{array}$ & $\begin{array}{c}23.71 \\
(29.13)\end{array}$ & $\begin{array}{c}30.37 \\
(33.44)\end{array}$ & $\begin{array}{c}34.07 \\
(35.71)\end{array}$ \\
\hline 3. & Norium oleander & $\begin{array}{l}22.96 \\
(28.63)\end{array}$ & $\begin{array}{c}28.89 \\
(32.51)\end{array}$ & $\begin{array}{c}30.37 \\
(33.44)\end{array}$ & $\begin{array}{l}19.26 \\
(26.03)\end{array}$ & $\begin{array}{c}26.67 \\
(31.09)\end{array}$ & $\begin{array}{c}29.63 \\
(32.97)\end{array}$ & $\begin{array}{l}14.07 \\
(22.03)\end{array}$ & $\begin{array}{c}19.26 \\
(26.03)\end{array}$ & $\begin{array}{l}21.48 \\
(27.61)\end{array}$ \\
\hline 4. & $\begin{array}{l}\text { Annona } \\
\text { squamosa }\end{array}$ & $\begin{array}{c}17.04 \\
(24.38)\end{array}$ & $\begin{array}{c}22.22 \\
(28.12)\end{array}$ & $\begin{array}{c}24.44 \\
(29.62)\end{array}$ & $\begin{array}{c}13.33 \\
(21.41)\end{array}$ & $\begin{array}{c}20.74 \\
(27.09)\end{array}$ & $\begin{array}{c}23.70 \\
(29.13)\end{array}$ & $\begin{array}{c}9.63 \\
(18.07)\end{array}$ & $\begin{array}{c}14.07 \\
(22.03)\end{array}$ & $\begin{array}{c}17.04 \\
(24.38)\end{array}$ \\
\hline 5. & $\begin{array}{l}\text { Cantharanthus } \\
\text { roseus }\end{array}$ & $\begin{array}{l}20.00 \\
(26.56)\end{array}$ & $\begin{array}{c}25.18 \\
(30.11)\end{array}$ & $\begin{array}{c}27.41 \\
(31.57)\end{array}$ & $\begin{array}{l}16.30 \\
(23.81)\end{array}$ & $\begin{array}{c}23.70 \\
(29.13)\end{array}$ & $\begin{array}{c}26.67 \\
(31.09)\end{array}$ & $\begin{array}{l}11.85 \\
(20.13)\end{array}$ & $\begin{array}{c}16.30 \\
(23.81)\end{array}$ & $\begin{array}{l}19.26 \\
(26.03)\end{array}$ \\
\hline 6. & Lantana camera & $\begin{array}{c}12.59 \\
(20.78)\end{array}$ & $\begin{array}{c}18.52 \\
(25.48)\end{array}$ & $\begin{array}{l}21.48 \\
(27.61)\end{array}$ & $\begin{array}{c}10.37 \\
(18.78)\end{array}$ & $\begin{array}{c}18.52 \\
(25.48)\end{array}$ & $\begin{array}{c}20.74 \\
(27.09)\end{array}$ & $\begin{array}{c}7.41 \\
(15.79)\end{array}$ & $\begin{array}{c}11.85 \\
(20.13)\end{array}$ & $\begin{array}{c}14.82 \\
(22.64)\end{array}$ \\
\hline 7. & $\begin{array}{l}\text { Pongamia } \\
\text { pinnata }\end{array}$ & $\begin{array}{c}28.15 \\
(32.04)\end{array}$ & $\begin{array}{c}34.82 \\
(36.16)\end{array}$ & $\begin{array}{c}38.52 \\
(38.36)\end{array}$ & $\begin{array}{l}23.70 \\
(29.13)\end{array}$ & $\begin{array}{c}31.85 \\
(34.35)\end{array}$ & $\begin{array}{c}34.82 \\
(36.16)\end{array}$ & $\begin{array}{l}19.26 \\
(26.03)\end{array}$ & $\begin{array}{c}24.45 \\
(29.63)\end{array}$ & $\begin{array}{c}27.41 \\
(31.44)\end{array}$ \\
\hline 8. & $\begin{array}{l}\text { Ocimum } \\
\text { sanctum }\end{array}$ & $\begin{array}{c}25.92 \\
(30.60)\end{array}$ & $\begin{array}{c}31.85 \\
(34.35)\end{array}$ & $\begin{array}{c}35.56 \\
(36.60)\end{array}$ & $\begin{array}{c}21.48 \\
(27.61)\end{array}$ & $\begin{array}{c}28.89 \\
(32.37)\end{array}$ & $\begin{array}{c}32.59 \\
(34.81)\end{array}$ & $\begin{array}{c}16.30 \\
(23.57)\end{array}$ & $\begin{array}{l}21.48 \\
(27.61)\end{array}$ & $\begin{array}{c}24.45 \\
(29.63)\end{array}$ \\
\hline 9. & $\begin{array}{l}\text { Dhatura } \\
\text { stramonium }\end{array}$ & $\begin{array}{c}31.11 \\
(33.71)\end{array}$ & $\begin{array}{c}37.78 \\
(37.84)\end{array}$ & $\begin{array}{c}41.48 \\
(40.09)\end{array}$ & $\begin{array}{c}26.67 \\
(30.99)\end{array}$ & $\begin{array}{c}34.82 \\
(36.16)\end{array}$ & $\begin{array}{c}37.78 \\
(37.92)\end{array}$ & $\begin{array}{c}21.48 \\
(27.61)\end{array}$ & $\begin{array}{c}26.67 \\
(31.09)\end{array}$ & $\begin{array}{c}30.37 \\
(33.44)\end{array}$ \\
\hline 10. & $\begin{array}{l}\text { Apocynum } \\
\text { cannabium }\end{array}$ & $\begin{array}{c}9.63 \\
(18.07)\end{array}$ & $\begin{array}{c}15.56 \\
(23.23)\end{array}$ & $\begin{array}{c}(25.18 .52 \\
13)\end{array}$ & $\begin{array}{c}6.67 \\
(14.96)\end{array}$ & $\begin{array}{c}14.82 \\
(22.64)\end{array}$ & $\begin{array}{c}17.78 \\
(24.93)\end{array}$ & $\begin{array}{c}5.18 \\
(13.15)\end{array}$ & $\begin{array}{c}8.89 \\
(17.34)\end{array}$ & $\begin{array}{c}11.85 \\
(20.13)\end{array}$ \\
\hline 11. & Alcohol & $\begin{array}{c}42.22 \\
(40.52)\end{array}$ & $\begin{array}{c}51.11 \\
(45.63)\end{array}$ & $\begin{array}{c}54.82 \\
(47.76)\end{array}$ & $\begin{array}{c}35.56 \\
(36.57)\end{array}$ & $\begin{array}{c}44.44 \\
(41.80)\end{array}$ & $\begin{array}{c}48.89 \\
(44.35)\end{array}$ & $\begin{array}{c}29.63 \\
(32.97)\end{array}$ & $\begin{array}{c}36.29 \\
(36.99)\end{array}$ & $\begin{array}{c}40.74 \\
(39.66)\end{array}$ \\
\hline 12. & Control & $\begin{array}{c}2.96 \\
(9.90)\end{array}$ & $\begin{array}{c}2.22 \\
(8.56)\end{array}$ & $\begin{array}{c}2.96 \\
(9.90)\end{array}$ & $\begin{array}{c}1.48 \\
(6.98)\end{array}$ & $\begin{array}{c}0.74 \\
(4.93)\end{array}$ & $\begin{array}{c}10.37 \\
(18.78)\end{array}$ & $\begin{array}{c}0.74 \\
(4.93)\end{array}$ & $\begin{array}{c}2.22 \\
(8.56)\end{array}$ & $\begin{array}{c}0.74 \\
(4.93)\end{array}$ \\
\hline & SE & 1.48 & (1.26) & 1.42 & 1.16 & $(1.20)$ & (1.36) & 1.12 & $(0.84)$ & (1.07) \\
\hline & $\mathrm{CD}$ & $(3.04)$ & (2.60) & (2.94) & (2.39) & (2.48) & $(2.80)$ & $(2.30)$ & $(1.75)$ & (2.20) \\
\hline
\end{tabular}

Figures in parentheses are angular transformed values; Note: The data given in table 4 are the mean of mortality per cent of maggots after $6^{\text {th }}, 8^{\text {th }}$ and $10^{\text {th }}$ days of spray of indigenous plant extract.

Fig.1 Mortality (\%) of maggots of guava fruit fly Bactrocera correcta at 2, 5 and 8 per cent plant extracts on I larval instar stage

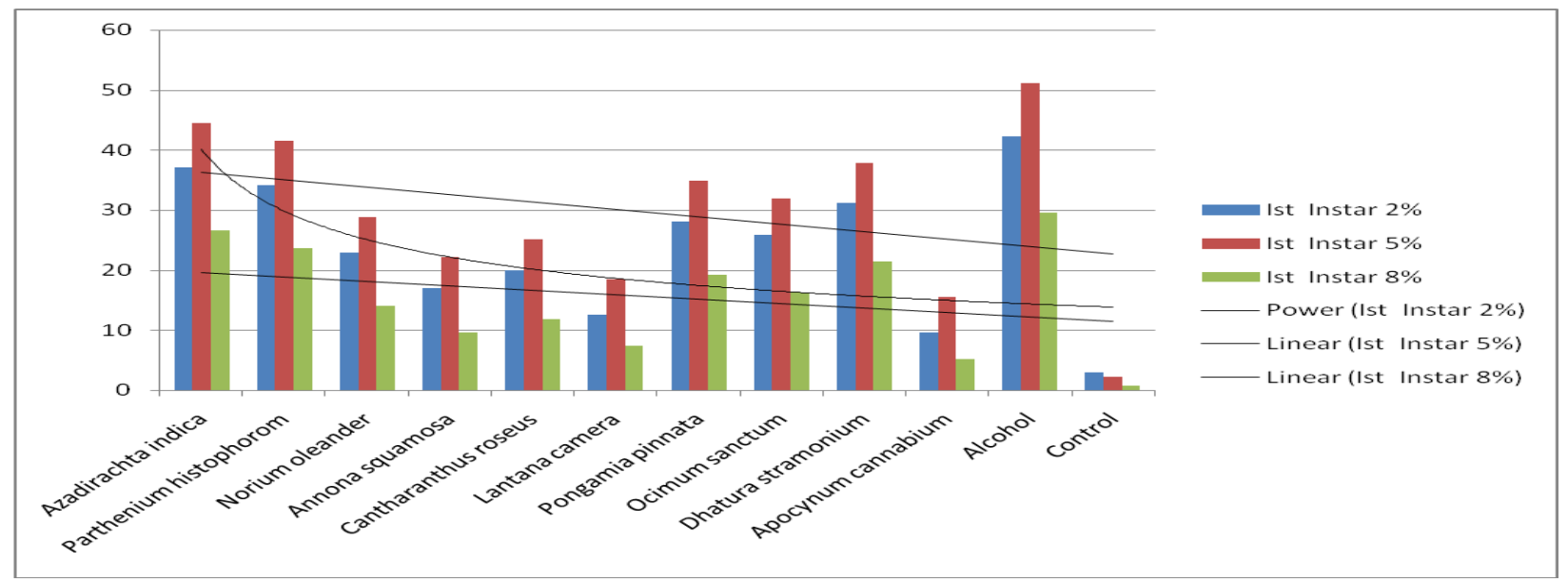


Fig.2 Mortality (\%) of maggots of guava fruit fly Bactrocera correcta at 2, 5 and 8 per cent plant extracts on II larval instar stage

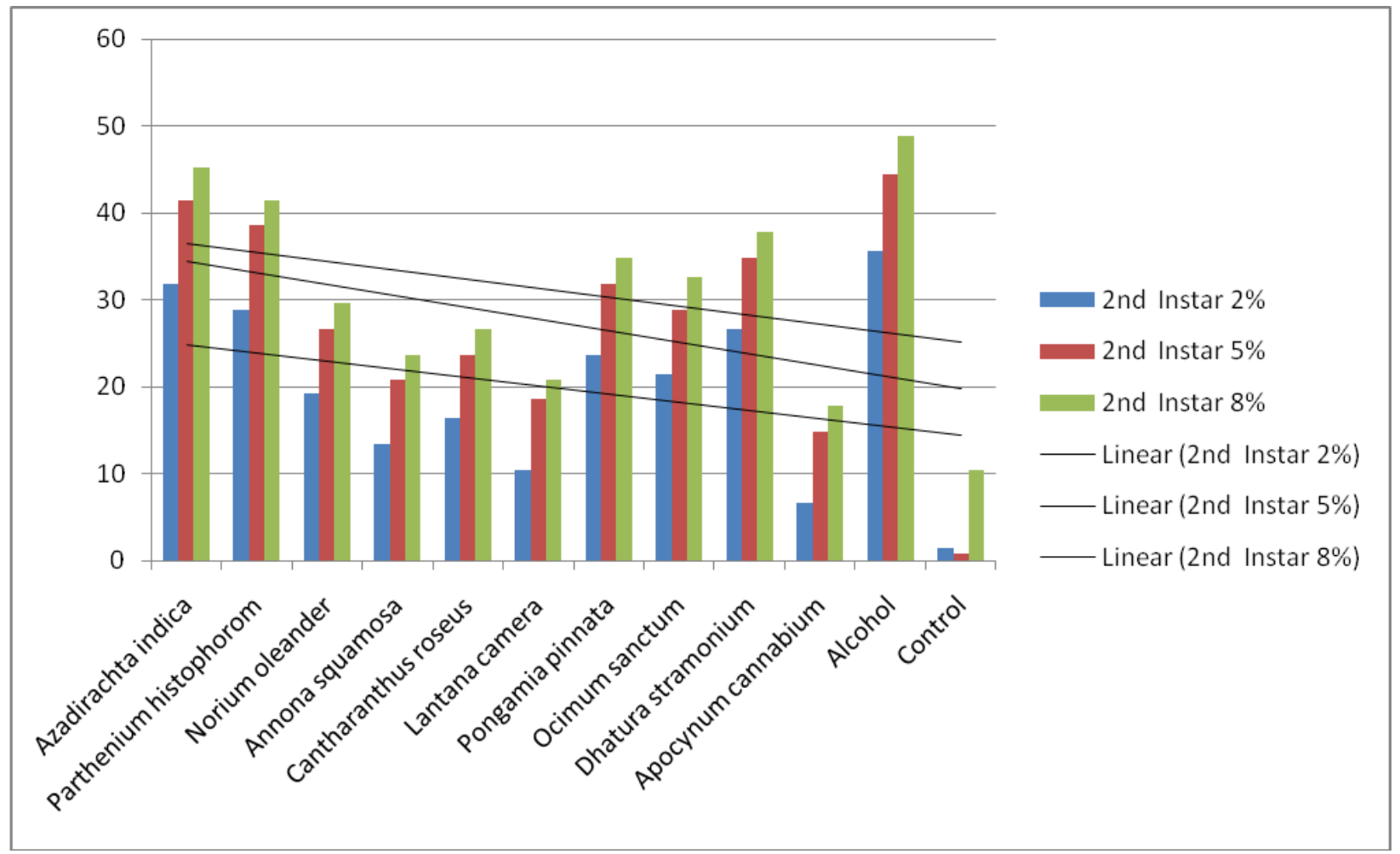

Fig.3 Mortality (\%) of maggots of guava fruit fly Bactrocera correcta at 2, 5 and 8 per cent plant extracts on III larval instar stage

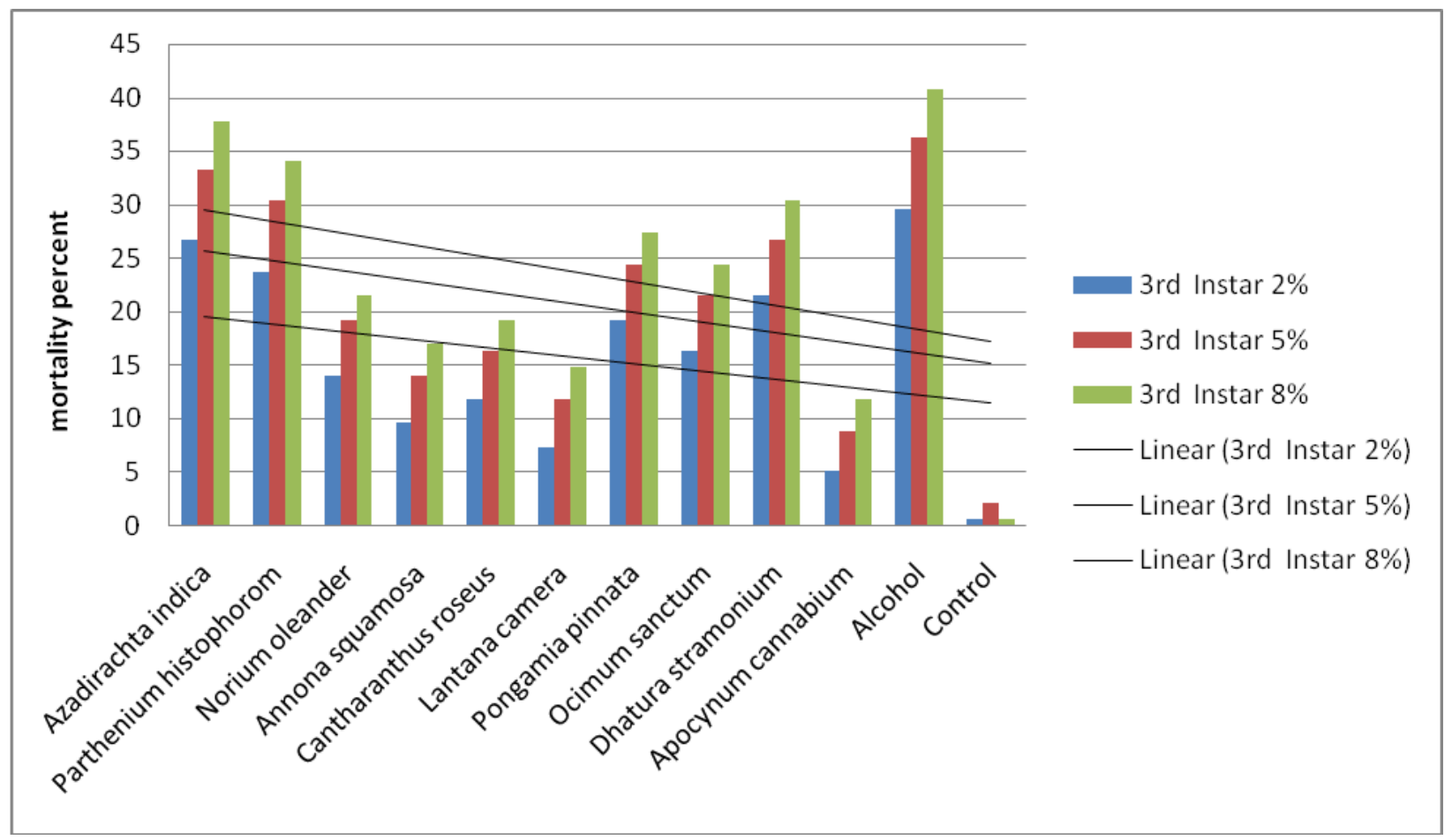


Our study clearly revealed the susceptibility of $B$. correcta to different indigenous plants as indicated by their deleterious effect on growth and development of guava fruit fly which could be more beneficial to farmers growing guava in India where it is known as poor man's 'apple', however, farmers need to be trained to be successful.

In conclusion, tropical countries have rich Bio-diversity of plants in which botanical pesticides are emerging as a fast and viable component of integrated pest management tools because of its eco-friendly nature. The toxic effect of plant extract is synergistic effect of secondary compounds which are postulated to have evolved for the plants defence. These compounds confirm protection to crop through reduction of fitness to insect herbivores. Neem and Parthenium are found more or less everywhere and they can be utilized as growth inhibitory tools in insect pest management. Although the plant extracts may be less toxic, they are relatively safe and eco-friendly.

\section{Author contribution statement}

NA suggested and formulated, comprehended and designed the experiments, SKV performed the experiments in laboratory as Ph.D. Scholar while RK developed the tables, graphs and computer application in statistical analysis and all authors wrote the manuscript. This technique can be applied to find other indigenous plants/botanicals to exploit their uses as growth regulator, egg laying inhibitor and may have insecticidal properties in the era of chemical pesticide that is becoming a health hazards in $21^{\text {st }}$ century where people are very conscious to their health

\section{Acknowledgements}

This study of experiment is purely part of the Ph.D. thesis work conducted during the 2011-
12 in the Department of Entomology at Chandra Shekhar Azad university of Agriculture and Technology, Kanpur. We thank the head of the department Dr. R. S. Singh for providing all the necessary equipments, chemicals and facilities in the Ph.D. Laboratory. We also thank Head department of Horticulture, CSAUAT Kanpur for allowing collection of guava from orchards as and when required.

\section{References}

Agrawal, Neerja and Saroj, S.R. 2003. Bioefficacy of fresh neem oil obtained from fresh samples against larvae of mustard sawfly Athalia proxima Klug. infesting mustard. J. Entomol. Res. 27(4): 347-351

Agrawal, Neerja and Dev, I. 2013a. Preliminary bio efficacy of Neem and other botanicals for the management of melon fruit fly Bactrocera cucurbitae Coqe. Insect Environ. 19(1): 5-7.

Agrawal, Neerja and Dev, I. 2015. Bioefficacy of Neem and other botanicals for melon fruit fly Bactrocera cucurbitae management. Current Advances Agri. Sci. 7(1): 91-92.

Anonymous, 2015. Dacine Fruit Flies of the AsiaPacific. http://www.harbarium. hawaii.edu/fruitfly/2015.

Bezzi, M., 1916. On the fruit-flies of the genus DacusOccurring in India, Burma, and Ceylon. B. Entomol. Res. 7: 99-121.

Chien-Chung Chen, Yaw-Jen Dong, Ling- Lan Cheng and Roger Hou. 1996. Deterrent effect of Neen seed kernel extract on oviposition of the oriental fruit fly (Diptera: Tephritidae). J. Econ. Entomol. 89(2): 462466.

Drew, R.A.I., Raghu, S., 2002. The fruit fly fauna (Diptera: Tephritidae: Dacinae) of the rainforest habitat of the Western Ghats, India. Raffles B. Zool. 20: 327-352.

Fakhri, M.S.A. and Murad, N.2004. Effect of neem product on different life stages of Dysdercus koenigi fabr. (Hemiptera: Pyrrhocoridae). Indian J. Entomol. 66(4): 349-353.

Fernandez-Alba, A.R. and Garc a-Reyes, J.F., 2008. Large-scale multi residue methods 
for pesticides and their degradation products in food by advanced LC-MS. Trac-Trend. Anal. Chem. 27(11): 973-990.

Hasan, E.1998. Insecticidal toxicity of neem seed kernel extract (NSKE) on Bactrocera tryoni (Frogg) (Diptera: Tephritidae) and repellency on persimmon fruit. Zeitschrift fur Pflanzenkrankheiten und Pflansenschut. 105(4): 411-416.

Haseeb, M. 2005. Current studies in insect pest problem in guava. ISHS Ist International guava symposium, pp 735

Karnataka, D.C., Thakur, S.S.and Karnatak, A.K., 2007. Effect of Ocimum leaf extract on development of Spilarctia obliqua. Annals Plant Prot. Sci. 15(2): 482-483.

Kaur, A., Sohal, S.K., Singh, R. and Arora, S. 2010. Development inhibitory effect of Acacia auriculiformis extracts on Bactrocera cucurbitae (Coquillett) (Diptera: Tephretidae). J. Biopesticides. 3(2): 499- 504.

Khan, Mahfuza., Hossain Aftab, M., Islam Saidul, M., 2007. Effect of Neem Leaf Dust and commercial formulation of Neem compound on the longevity, fecundity and ovarion development of melon Fly, Bactrocera cucurbitae (Tephritidae): Pakistan J. Biol. Sci. 10(20): 3656-3661.

Kulkarni, N., Joshi, K.C., and Gupta, B.N., (1997). Antifeedant property of Lantana camara varaculeata and aloe vera leaves against Teak skeletonizer Eutectona machaeralis Walks. (Lepidoptera: Pyralidae). Entomon. 22(1): 61-65.

Mondal, Sujoy., Ghatak, S.S., (2009). Field testing of some indigenous plant products against fruit fly, Bactrocera cucurbitae Coq.) infesting cucumber. J. Entomol. Res.
332(2): 133-137.

Ramesh, T, Devi, N.K.A. and Manoharan, T. 2006. Efficacy of selected plant extracts on the larvicidal and repellent action against Culex quinquefaciatus (Diptera: Culicidae). Indian J. Entomol. 68(3): 210-212.

Sharma, V and Rathor, Y. S., 2006. Effect of some botanicals on adult emergence, oviposition and development of Callosobruchus chinensis (Linn.) on pigeon pea grains. Indian J. Entomol. 68(1): 74-77.

Shaivayya, V. And Kumar, C.T.A. 2008. Management of melon fruit fly Bactrocera cucurbitae Coq. On bitter gourd Momardica charantia Linn. By using plant products. Environ. Ecol. 26(1A): 245-249.

Siskos, E.P., Konstantopoulou, M.A., Mazomenos, B.E., Jervis, M., 2007. Insecticidal activity of Citrus aurantium fruit, leaf and shoot extracts against adult olive fruit flies (Diptera: Tephritidae), J. Econ. Entomol. 100(4): 1215-1221.

Stark, J.D., Vargas, R.I., Thalman, R.K., 1990. Azadirachtin: effects on metamorphosis, longevity and reproduction of three tephritid fruit fly species (Diptera: Tephritidae). J.f Econ. Entomol. 83(6): 2168-2174.

Tiwari, K. K., 2001. Effect of plant extracts spray on fruit fly transmission of cucumber mosaic virus. J. Phyt. Res. 14: 207-208.

Wang, X.J., 1996. The fruit flies (Diptera: Tephritidae) of the East Asian region. Acta Zool. Sinica, 21: 52.

White, I.M., Elson-Harris M.M., 1992. Fruit flies of economic significance: Their identification and bionomics; CABI International: Wallingford, UK., pp.601

\section{How to cite this article:}

Neerja Agrawal, Shyam Kumar Verma and Ram Kewal. 2019. Plant Extract Approaches to the Management of Guava Fruit Fly Bactrocera correcta (Bezzi). Int.J.Curr.Microbiol.App.Sci. 8(05): 2027-2037. doi: https://doi.org/10.20546/ijcmas.2019.805.235 